\title{
BENDING MOMENT RESISTANCES OF L-SHAPED FURNITURE FRAME JOINTS UNDER TENSION AND COMPRESSION LOADINGS
}

\author{
Selçuk Demirci \\ Ege University \\ TuRKEY \\ Harun Diler \\ Akdeniz University \\ TurkeY \\ Ali Kasal \\ Mugla Sitki Kocman University \\ TurKeY \\ Yusuf ZiYa Erdil \\ Mugla Sitki Kocman University \\ TuRKey \\ (RECEIVED JANUARY 2020)
}

\begin{abstract}
Effect of wood species, joint techniques, and adhesive type on bending moment resistances were investigated. $480 \mathrm{~L}$-shaped joint specimens were tested including 2 loadings, 4 wood species, 3 joint techniques, 2 adhesives, and 10 replications. Specimens were prepared from Scotch pine, Oriental beech, oak, and chestnut. The joint techniques were dowel, half lap and open mortise and tenon, and type of adhesives were polyvinyl acetate (PVAc) and polyurethane (PU). Bending moment resistance of the joints under compression ranged from a low of $60 \mathrm{Nm}$ for Scotch pine dowel joints with PVAc to oak half lap joints a high of $281 \mathrm{~N} \cdot \mathrm{m}$ w/PVAc. Bending moment resistance of the joints loaded in tension ranged from a low of $230 \mathrm{~N} \cdot \mathrm{m}$ for scotch pine dowel joints w/PVAc and to a maximum of $917 \mathrm{~N} \cdot \mathrm{m}$ for oak half lap joints w/PVAc. Highest average moment resistance was achieved with oak half lap jointed specimens w/PVAc, under both loadings.
\end{abstract}

KEYWORDS: Furniture frame joints, dowel, half-lap, moment resistance. 


\section{INTRODUCTION}

There are many joint techniques used in the corner joints of furniture constructions. The most commonly used of these joints are dowel, lap, and open mortise and tenon joints. L-shaped furniture joints are frequently used in doors, windows, advertisement cabinets and frame construction furniture.

The dowels are applied to the side of one of the wood materials to be joined and to the end of the other. The drilled hole diameters are $1 / 3$ or $1 / 2$ of the material thickness. The hole depth is about $20 \mathrm{~mm}$. Half lap joints are the simplest of frame corner joints. In these assemblies, the same process is applied to both wood materials. For this reason, this is very practical. In half lap joints, the notch is half the thickness of the material. The depth of the notch is up to the material width. Mortise and tenon joints are the most commonly used joint type in wooden frame corner joints. It is an easy and solid combination. The thickness of the tongue in these joints is $1 / 3$ of the thickness of the material. The width is the width of the material.

Murphey and Rishel (1972) claimed that mortise and tenon and dowel joints are the most common furniture joinery techniques. Eckelman (2003) stated that one of the most important step in the strength design process consists of designing the joints. He argued that more furniture has failed because of weak joints than from any other single cause.

Wilczyński and Warmbier (2003) analyzed the influence of joint dimensions on the bending strength and stiffness of mortise and tenon joints. This study showed that the influence of joint dimensions on mechanical properties of the tenon joint can be expressed by means of regression functions in the form of a second power polynomial with interactions or in the form of a power functions product. The bending strength and stiffness of the joint increase as the tenon dimensions increase. The greatest effect on the joint strength has the tenon length, the influence of the tenon width is less significant and the effect of the tenon thickness is slight. The joint stiffness depends first of all on the tenon width, the effects of the tenon length and thickness are less significant.

Adhesives are very important for joints since they create a continuous fastening as an alternative to expensive mechanical connectors. PVAc and PU based adhesives are used in furniture joinery owing to the advantages of curing in room temperature. PU adhesives have single component (Lange et al. 2001) and double component (Chen and Walworth 2001) formulas which are utilized as joint glues. Dzincic and Skakic (2012) studied the influence of fit in mortise and tenon joints. They found that glued line should be uninterrupted along the joint surface and there should be certain amount of gap for that.

Eckelman et al. (2004) found that the shoulders on tenons significantly increase the bending moment capacity of a joint when the shoulders of the tenon fit firmly against the side of the member in which the tenon is inserted.

Erdil et al. (2005) determined that a mortise and tenon joint becomes stiffer as either tenon length or tenon depth is increased. The results also indicate that tenon depth has a more significant effect on joint flexibility than tenon length. Furthermore, the presence of a shoulder on the rail member of a mortise -tenon joint substantially contributes to the stiffness of the joint. An empirically derived expression was developed to predict average ultimate bending moment capacity. Semi-rigid connection factors were also determined.

Aman et al. (2008) in this study describes results from a series of experiments aimed at comparing the loose tenon joint with the conventional mortise and tenon, and dowel joints for three wood species. It is indicated that loose tenon joint strength falls somewhere between that of the dowel joint and the conventional mortise and tenon joint. 
Prekrat and Smardzewski (2010) determined that properly executed and well solidified superellipse glue bonds, in comparison with rectangular bonds, increase four-fold the strength of the tenon joint at the identical operational loads. In the case of rectangular gluelines, shear stresses are of destructive nature and are distributed nonlinearly along all its edges. In super ellipse glue bonds, the greatest shear stresses occur on one edge adjoining the tenon offset. As the result of the pressure of the tenon on the mortise via the super ellipse glue bond, the highest normal stresses are generated which reduce significantly shear stresses. In industrial practice, it is important to apply glue on the entire surface of the tenon and mortise.

Cagatay (2011) found that at all joining members and techniques, beech and walnut usually scored over other wood species. The lowest values were obtained from the chestnut and scotch pine. The best results of joining techniques were obtained from mortise and tenon joints, while the lowest results were obtained from maxifix and minifix joints. At glued joints, polyvinyl acetate glue rather than polyurethane glue and grooved joints rather than dowel yielded better results. At the dowel joint test specimens which were made by using Strain gauges, close results to the results calculated theoretically are obtained, on the other hand, at the test specimens mortise and tenon joint applied, the results are not close, thus coefficients of error were identified.

Kamperidou et al. (2011) evaluated the strength of the three most frequent joints in the upholstered furniture frames made of beech and poplar sold wood. The stiffness and strength of the three most frequently used joints in upholstered furniture frames, constructed of beech and poplar. The research was carried out in the following joints: Mortise -Tenon, double dowel and double Gusset Plates, which were constructed and tested in both corner and middle Joints. It was examined that four different joints were strongly correlated to the values of the corresponding joints, whether they were constructed with beech or poplar wood. Also, a correlation was noticed between the bending strength values of the joints constructed and the bending strength values of the respective joints made of the poplar wood. Relative to tension values, a strong relationship was also recorded between the beech wood joints and the poplar ones. Based on these results, it is concluded that the tension strength values of these joints could be estimated by the measured bending strength values of the corresponding joints.

Dalvand et al. (2013) examined the effect of joint type, and number and types of dovetail keys on diagonal tension and compression performance of corner joints in a furniture frame. According to the result mitered joints were stronger than butted ones. Butterfly dovetail keys were superior to $\mathrm{H}$ shape keys. Double keys performed better than single key. Experimental joints glued with PVAc were stronger than those glued with CA glue and control specimens. In terms of strength, butterfly dovetailed joints were comparable with doweled joints.

Hrovatin et al. (2013) studied the strength of joints with a wooden ring. These results showed that the average ultimate strength of joints with a wooden ring was higher than the ultimate strength of tenon joints, which was chosen as an upper reference limit.

Imirzi et al. (2015) determined that the highest stiffness/strength values were estimated in mortise and tenon joints constructed of white oak, whereas dowel joints constructed from Turkish beech showed the lowest stiffness/strength and deformability. The elasticity modulus of the experimental joints expressed their stiffness better than the stiffness coefficient. The accuracy of the developed elasticity modulus model of the examined joints was verified positively both by experimental studies and numerical calculations.

Kasal et al. (2015) indicated that the moment capacity increased as either tenon width or length increased. The results also indicated that tenon length had a greater effect on the moment capacity than tenon width. In both compression and tension tests, Turkish beech joints were stronger than Scotch pine joints, and PU joints were stronger than PVA joints. An empirically 
derived expression was developed to estimate the average ultimate bending moment capacity of joints under compression and tension loads as functions of the wood species, the adhesive type, and the tenon size.

Nicholls and Crisan (2002) suggested that both static and dynamic forces are exerted to furniture in use. Therefore, joints have to be designed to resist such loads. Empirical testing is very common to observe the performance of joints. However, recently, many researchers (Hu and Guan 2017, Derikvand and Ebrahimi 2014, Hu 2015, Huyuk and Musica 2014, Kasal et. al 2016, Li 2010) utilized finite element analysis techniques to simulate the actions and theoretically analyze the strength behavior of joints.

Vassiliou et al. (2016) determined that mortise-tenon joint in combination with PVAc, provided the best strength results for all wood species. In almost all cases, the joint of mortisetenon revealed better strength results compared to the double dowel joint, referring to either PVAc or PU adhesive, except for mortise-tenon joint made of beech with PU adhesive that exhibited lower strength compared to the double dowel joint in the presence of PVAc adhesive.

In service, L-shaped furniture frame joints would be expected to be loaded either in tension or compression, or both, and it is important to evaluate the bending moment resistances of these joints under either type of loading. There is little information available, however, concerning the bending moment resistances of L-shaped joints constructed with different techniques, adhesives, and wood species. This study, was carried out, accordingly, to determine the effects of the adhesive type, joint techniques on bending moment resistances under tension and compression loadings by using L-shaped furniture frame joints constructed of different wood species.

\section{MATERIAL AND METHODS}

\section{Wood materials and adhesives}

In this study, Scotch pine (Pinus sylvestris L.), Oriental beech (Fagus orientalis L.), Oak (Quercus petrea) and Chestnut (Castanea sativa M.) were used for constructing the specimens. These species are widely utilized in the manufacturing of furniture frames. Wood materials were randomly selected from the commercial suppliers in Ankara, Turkey. Average density values were $0.52,0.66,0.68$, and $0.63 \mathrm{~g} \cdot \mathrm{cm}^{3}$, for Scotch pine, Oriental beech, oak, and chestnut, respectively. In the assembling of specimens, two adhesive types were used, namely, polyvinyl acetate (PVAc) and polyurethane (PU). PVAc adhesive was utilized because of its useful properties such as cold application, easily spreading, rapidly drying, to be scentless and fireproof, and being preferred in the production of the sofa frames. Some properties of the adhesive utilized were given by the producer firm as density of $1.1 \mathrm{~g} \cdot \mathrm{cm}^{3}$, viscosity of $160-200 \mathrm{cps}, \mathrm{PH}=5.00$, ash rate of $3 \%$. PU adhesive has only one component which has a high resistance to water and humidity. This adhesive is excellent for wood, metal, polyester, stone, ceramic, PVC (polyvinyl chloride) and other plastics. It is especially suitable for marine structures and the external face of buildings. Cohesive strength of the polyurethane glue is higher than the bonding strength. Glue line thickness varies between 0.10 and $0.15 \mathrm{~mm}$ during bonding.

\section{Preparation and construction of the L-shaped specimens}

The configuration and dimensions of the L-shaped joints used are shown in Fig. 1. It should be noted that in material preparation and assembly, small wood-shop techniques were utilized. All of the wood used in this study was cut from air-dried timbers by means of a band saw.

Dowel, half lap and open mortise and tenon joints were used in the present study as 3 types of commonly employed practice joint techniques in the construction of furniture frames. The 
dimensions of the $\mathrm{L}$-shaped joints used and the mutual positions of individual furniture elements are shown in Fig. 1.

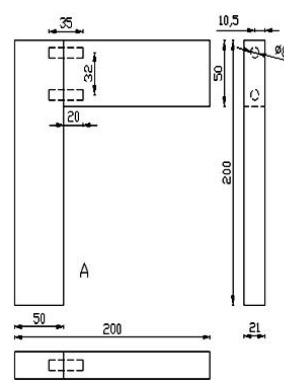

A: Dowel joint

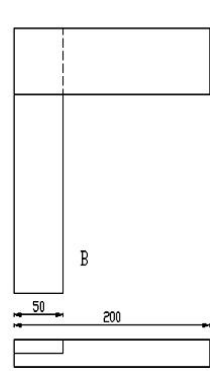

B: Half lap joint

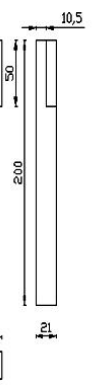

C: Mortise and tenon joint

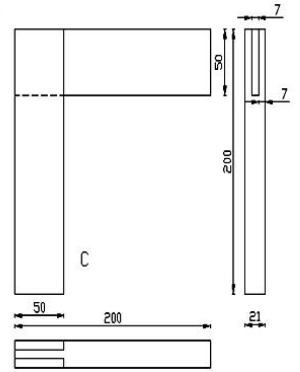

Fig. 1: Dimensions of the specimens tested ( $\mathrm{mm}$ ).

In assembling the joints, adhesives were applied liberally (approximately $150 \pm 10 \mathrm{~g} \cdot \mathrm{cm}^{-2}$ ) to the dowel, lap surface or tenon faces (cheeks) and to the dowel holes or walls of the mortises. After the application, specimens were pressed together for approximately 1.5 hours at $20^{\circ} \mathrm{C}$ temperature. Then, specimens were allowed to cure for at least one month before testing in an environmentally controlled conditioning room that was set to produce an average equilibrium moisture content of $12 \%$. The determination process of moisture contents (MC) and densities of the wooden materials were performed according to the procedure of ASTM D 4442 (2001) and ASTM D 143-94 (2000), respectively.

\section{Experimental design}

Altogether, 480 specimens (240 tension +240 compression) with 10 replications x 4 wood species (Scotch pine, oriental beech, oak, and chestnut) x 3 joint techniques (dowel, half lap, and open mortise and tenon joints), 2 adhesive types (PVA and PU) were prepared and tested to determine the bending moment capacity of L-shaped joints.

Full linear models (Model 1, Model 2) for the three-way factorial experiments were utilized to determine the effects of wood species, joint techniques and adhesive types on moment resistance of L-shaped joints. The models are as follows:

$$
\begin{aligned}
& \mathrm{TM}_{\mathrm{ijkl}}=\mu_{1}+\mathrm{A}_{\mathrm{i}}+\mathrm{B}_{\mathrm{j}}+\mathrm{C}_{\mathrm{k}}+(\mathrm{AB})_{\mathrm{ij}}+(\mathrm{AC})_{\mathrm{ik}}+(\mathrm{BC})_{\mathrm{jk}}+(\mathrm{ABC})_{\mathrm{ijk}}+\varepsilon_{\mathrm{ijk} 1} \\
& \mathrm{CM}_{\mathrm{ijk} \mathrm{l}}=\mu_{2}+\mathrm{A}_{\mathrm{i}}+\mathrm{B}_{\mathrm{j}}+\mathrm{C}_{\mathrm{k}}+(\mathrm{AB})_{\mathrm{ij}}+(\mathrm{AC})_{\mathrm{ik}}+(\mathrm{BC})_{\mathrm{jk}}+(\mathrm{ABC})_{\mathrm{ijk}}+\varepsilon_{\mathrm{ijk} 1}
\end{aligned}
$$

where: $\mathrm{TM}_{\mathrm{ijkl}}$ and $\mathrm{CM}_{\mathrm{ijkl}}$ refer to the moment resistance $(\mathrm{Nm})$ of $\mathrm{L}$-shaped joints, respectively; $\mu_{1}$ and $\mu_{2}$ refer to the population means for the moment resistance $(\mathrm{Nm})$ for all wood species-joint technique-adhesive type combinations, respectively; A refers to the discrete variable representing the effect of wood species; B refers to the discrete variable representing the effect of joint technique; $\mathrm{C}$ refers to the discrete variable representing the effect of adhesive type; $(\mathrm{AB})$ refers to the effect of the two-way interaction among the wood species-joint technique; (AC) refers to the effect of the two-way interaction among the wood species-adhesive type; (BC) refers to the effect of the two-way interaction among the joint technique-adhesive type; (ABC) refers to the effect of the three-way interaction among the three variables; $\varepsilon$ refers to the random error term; i refers to the index for wood species, $1, \ldots, 4 ; \mathrm{j}$ refers to the index for joint technique, $1, \ldots, 3 ; \mathrm{k}$ refers to the index for adhesive type, $1, \ldots, 2$; and 1 refers to the index for the replication, $1, \ldots, 10$. 


\section{Tension and compression loading tests of joints}

In everyday use, the corner joints of frame furniture are exposed to two main forces: tension and compression. Most of these forces are applied through cantilevers (long sides) and can generate sizable bending moments. Fig. 2 shows loading diagrams in testing corner joint moment resistances to tension forces that tend to open the corner joints and compression forces that tend to close the corner joints, respectively.
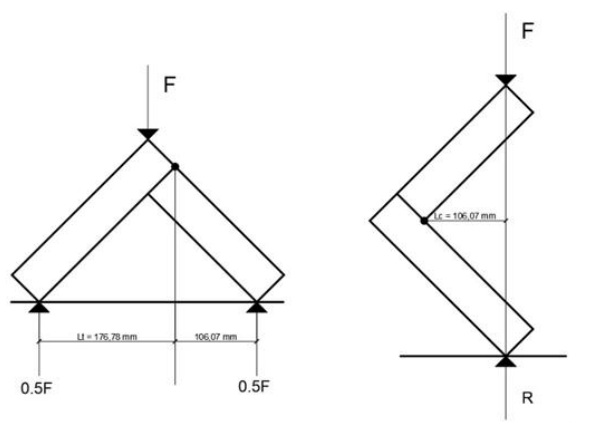

Fig. 2: Method of joint loading. A: Under tension, B: Under compression.

All tests were carried out on a $30 \mathrm{kN}$ capacity universal-testing machine. The moment arm was measured as $0.106 \mathrm{~m}$ for compression loading; while it was $0.177 \mathrm{~m}$ for tension because of the asymmetrical pivot point (Fig. 2). The rate of static loading was $2 \mathrm{~mm} \cdot \mathrm{min}^{-1}$. In the tension tests, the bottoms of each of the two legs of the joints were placed on rollers so that the two joint members were free to move outwardly as the joint was loaded. The loading was continued until a non-recoverable drop in load occurred. A total of $480 \mathrm{~L}$-shaped specimens were tested; 240 were tested in tension and the remaining 240 in compression. Test set-ups are shown in Fig. 2.

In the tests, maximum load capacities were recorded in Newton $(\mathrm{N})$. However, the supports are outside in the diagonal tension and the rotation center point is out of the force direction in the compression tests. Therefore, the bending moments occurred at the corner joints in both loading conditions, so, maximum load capacities were converted to corresponding bending moment resistances of the joints (TM, CM) for both loadings by means of the expressions;

For the tension test,

For the compression test,

$$
\begin{array}{ll}
\mathrm{T}_{\mathrm{M}}=\mathrm{F}_{\operatorname{maxt}} / 2 \times \mathrm{L}_{\mathrm{t}} & (\mathrm{Nm}) \\
\mathrm{C}_{\mathrm{M}}=\mathrm{F}_{\operatorname{maxc}} \times \mathrm{L}_{\mathrm{c}} & (\mathrm{Nm})
\end{array}
$$

\section{RESULTS AND DISCUSSION}

In general, all joint failures occurred in 60-90 seconds. Half lap and mortise-and-tenon joints failed with modes of glue-line fracture, wood shear, and split in mortises. Dowel joints failed with modes of glue-line fracture, dowel surface shear (parallel to grain), and dowel fracture. Failures were generally abrupt with a cracking sound and separation of members from opening side of joint. Some crushing was observed especially with scotch pine and beech members form the pivot point ends of joints.

Grouping data for L-shaped joints subjected to compression loading showed a mean bending moment resistance of $153.82 \mathrm{Nm}$ while grouping data of L-shaped joints tested in tension loading resulted a mean bending moment capacity of $536.33 \mathrm{Nm}$. Thus, moment capacities for 
Vol. 65 (6): 2020

the L-shaped joints loaded in compression averaged $28.7 \%$ of the joints loaded in tension. The evaluation of the test results for tension and compression strength is given below separately.

\section{Bending moment resistances under tension loadings}

Multiple variance analysis was performed on the data obtained from a total of 240 specimens for determining the effect of wood species, joint techniques and adhesive type on the bending moment resistance under tension loading. The results of the variance analysis are shown in Tab. 1.

Tab. 1: Summary of the ANOVA results for bending moment resistances under tension.

\begin{tabular}{|l|c|c|c|c|c|}
\hline \multicolumn{1}{|c|}{ Source } & $\begin{array}{c}\text { Degrees of } \\
\text { freedom }\end{array}$ & Sum of squares & Mean squares & F value & $\begin{array}{c}\text { Prob. } \\
\text { (sig. 5\%) }\end{array}$ \\
\hline Wood species (A) & 3 & 394619 & 131540 & 61.17 & 0.000 \\
\hline Joint techniques (B) & 2 & 353550 & 176775 & 82.21 & 0.000 \\
\hline Adhesive type (C) & 1 & 103822 & 103822 & 48.28 & 0.000 \\
\hline A x B & 6 & 683867 & 113978 & 53.00 & 0.000 \\
\hline AXC & 3 & 387752 & 129251 & 60.11 & 0.000 \\
\hline BXC & 2 & 705751 & 352875 & 164.10 & 0.000 \\
\hline AXBXC & 6 & 360046 & 60008 & 27.91 & 0.000 \\
\hline Error & 216 & 464485 & 2150 & - & - \\
\hline Total & 239 & 3453892 & - & - & - \\
\hline
\end{tabular}

According to the results of this analysis, the effects of the main factors including wood species $(A)$, joint techniques $(B)$ and adhesive type $(C)$ were found to be statistically significant at the level of 0.05 . Furthermore, two factor interactions of wood species $\mathrm{x}$ joint techniques $(A \times B)$, wood species $\mathrm{x}$ adhesive type $(A \times C)$, joint techniques $\mathrm{x}$ adhesive type $(B \times C)$ were also statistically significant $(\mathrm{p} \leq 0.05)$. Three factor interactions of wood species $\mathrm{x}$ joint techniques $\mathrm{x}$ adhesive type $(A \times B \times C)$ were also statistically significant $(\mathrm{p} \leq 0.05)$. Therefore, the least significant difference multiple comparisons procedure at 5 percent significance level were performed to determine the mean differences of tension strength values of tested specimens considering the effect of wood species, joint techniques, and adhesive type interaction.

When the comparison results of wood species were examined, it was seen that the highest moment capacity was obtained in chestnut woods. Oak specimens gave results close to chestnut. The moment capacities of beech and pine woods were much lower. Comparison of results according to wood species are given in Tab. 2.

Tab. 2: Results of mean comparisons of bending moment resistances under tension for wood species (WS).

\begin{tabular}{|l|c|c|}
\hline \multirow{2}{*}{ Wood species } & \multicolumn{2}{|c|}{ Bending moment resistances under tension (N.m) } \\
\cline { 2 - 3 } & $\mathrm{X}$ & HG \\
\hline Scotch pine & 400.16 & $\mathrm{C}$ \\
\hline Oriental beech & 537.89 & $\mathrm{~B}$ \\
\hline Oak & 568.32 & $\mathrm{~B}$ \\
\hline Chestnut & 638.95 & $\mathrm{~A}$ \\
\hline
\end{tabular}

When the comparison results of the joint techniques were examined, it was seen that the highest moment capacity was obtained in the half lap joints. This was followed by mortise and tenon and dowel joints. The reason why half lap and mortise and tenon joints give better results 
maybe due to the fact that; it is believed that the joining surface area of these joints is higher. The dowel joints have much lower than the joining surface area. According to the interaction of the joint techniques, the comparison results are given in Tab. 3 .

Tab. 3: Results of mean comparisons of bending moment resistances under tension for joint techniques.

\begin{tabular}{|l|c|c|}
\hline \multirow{2}{*}{\multicolumn{1}{|c|}{ Joint technique }} & \multicolumn{2}{|c|}{ Bending moment resistances under tension (N.m) } \\
\cline { 2 - 3 } & $\mathrm{X}$ & HG \\
\hline Dowel & 487.55 & $\mathrm{~B}$ \\
\hline Half Lap & 568.26 & $\mathrm{~A}$ \\
\hline Open mortise and tenon & 553.18 & $\mathrm{~A}$ \\
\hline
\end{tabular}

When the comparison results of the adhesive type were examined, it was determined that PVAc glue gave better results than PU glue. This could be due to the better penetration of the glue into the pores of the woods in the joints made with PVAc glue. Comparison results according to adhesive type interaction are given in Tab. 4.

Tab. 4: Results of mean comparisons of bending moment resistances under tension for adhesive type.

\begin{tabular}{|l|c|c|}
\hline \multirow{2}{*}{ Adhesive type } & \multicolumn{2}{|c|}{ Bending moment resistances under tension $(\mathrm{N} \cdot \mathrm{m})$} \\
\cline { 2 - 3 } & $\mathrm{X}$ & $\mathrm{HG}$ \\
\hline $\mathrm{PVAc}$ & 591.65 & $\mathrm{~A}$ \\
\hline $\mathrm{PU}$ & 481.04 & $\mathrm{~B}$ \\
\hline
\end{tabular}

When the wood species, joint technique, and adhesive type triple comparison results are examined, the highest bending moment resistance was obtained with PVAc half lap joined oak specimens. The lowest moment capacity is obtained in dowel joints in Scotch pine wood. It was determined that the PVAc was more successful than the PU. Tab. 5 shows the results of wood species, joint technique, and adhesive type three-way interaction with confidence intervals.

Tab. 5: Results of mean comparisons for three-way interaction with confidence intervals.

\begin{tabular}{|c|c|c|c|c|c|c|}
\hline \multirow{2}{*}{ Adhesive } & \multirow{2}{*}{$\begin{array}{c}\text { Joint } \\
\text { technique }\end{array}$} & \multirow{2}{*}{$\begin{array}{l}\text { Wood } \\
\text { species }\end{array}$} & \multirow{2}{*}{ Mean } & \multirow{2}{*}{ Std. Error } & \multicolumn{2}{|c|}{ 95\% Confidence interval } \\
\hline & & & & & Lower bound & Upper bound \\
\hline \multirow{12}{*}{$\mathrm{PU}$} & \multirow{4}{*}{ dowel joint } & beech & 623.99 & 25.02 & 574.69 & 673.30 \\
\hline & & chestnut & 634.60 & 25.02 & 585.29 & 683.91 \\
\hline & & oak & 499.81 & 25.02 & 450.50 & 549.12 \\
\hline & & scotch pine & 288.57 & 25.02 & 239.27 & 337.88 \\
\hline & \multirow{4}{*}{ half lap joint } & beech & 233.77 & 25.02 & 184.47 & 283.08 \\
\hline & & chestnut & 631.06 & 25.02 & 581.76 & 680.37 \\
\hline & & \begin{tabular}{|l|} 
oak \\
\end{tabular} & 392.43 & 25.02 & 343.12 & 441.73 \\
\hline & & scotch pine & 490.53 & 25.02 & 441.23 & 539.84 \\
\hline & \multirow{4}{*}{$\begin{array}{l}\text { mortise and } \\
\text { tenon joint }\end{array}$} & beech & 552.84 & 25.02 & 503.53 & 602.15 \\
\hline & & \begin{tabular}{|l|} 
chestnut \\
\end{tabular} & 527.65 & 25.02 & 478.35 & 576.96 \\
\hline & & oak & 430.43 & 25.02 & 381.12 & 479.74 \\
\hline & & scotch pine & 466.67 & 25.02 & 417.36 & 515.98 \\
\hline
\end{tabular}


Vol. 65 (6): 2020

\begin{tabular}{|c|c|c|c|c|c|c|}
\hline \multirow{12}{*}{ PVAc } & \multirow{4}{*}{ dowel joint } & beech & 574.94 & 25.02 & 525.63 & 624.25 \\
\hline & & chestnut & 550.19 & 25.02 & 500.81 & 599.50 \\
\hline & & oak & 498.49 & 25.02 & 449.18 & 547.79 \\
\hline & & scotch pine & 229.80 & 25.02 & 180.49 & 279.10 \\
\hline & \multirow{4}{*}{ half lap joint } & beech & 570.96 & 25.02 & 521.66 & 620.27 \\
\hline & & chestnut & 779.99 & 25.02 & 730.69 & 829.30 \\
\hline & & oak & 917.43 & 25.02 & 868.13 & 966.74 \\
\hline & & scotch pine & 529.86 & 25.02 & 480.56 & 579.17 \\
\hline & \multirow{4}{*}{$\begin{array}{l}\text { mortise and } \\
\text { tenon joint }\end{array}$} & beech & 670.84 & 25.02 & 621.53 & 720.15 \\
\hline & & chestnut & 710.17 & 25.02 & 660.86 & 759.48 \\
\hline & & oak & 671.28 & 25.02 & 621.97 & 720.59 \\
\hline & & scotch pine & 395.52 & 25.02 & 346.21 & 444.83 \\
\hline
\end{tabular}

The load capacity results under tension loading obtained from this study have been compared with the results in study that were conducted by Imirzi et al. (2015). Generally, it could be said that the load capacities of dowel and mortise \& tenon joints constructed of beech and oak agree with the results obtained from this study. However, it is expected that there will be some differences between the load capacity values due to the differences in L-shaped specimen sizes and corresponding moment arms.

\section{Bending moment resistances under compression loadings}

Multiple variance analysis was performed on the data obtained from a total of 240 specimens for determining the effect of wood species, joint techniques, and adhesive type on the bending moment resistance under compression loading. The results of the variance analysis are shown in Tab. 6.

Tab. 6: Summary of the ANOVA results for bending moment resistances under compression.

\begin{tabular}{|l|c|c|c|c|c|}
\hline \multicolumn{1}{|c|}{ Source } & $\begin{array}{c}\text { Degrees of } \\
\text { freedom }\end{array}$ & Sum of squares & Mean squares & F value & $\begin{array}{c}\text { Prob. } \\
\text { (sig. 5\%) }\end{array}$ \\
\hline Wood species (A) & 3 & 30474 & 10158 & 18.37 & 0.000 \\
\hline Joint techniques (B) & 2 & 354891 & 177446 & 320.96 & 0.000 \\
\hline Adhesive type (C) & 1 & 72582 & 72582 & 131.29 & 0.000 \\
\hline A x B & 6 & 75681 & 12613 & 22.82 & 0.000 \\
\hline AXC & 3 & 42349 & 14116 & 25.53 & 0.000 \\
\hline BXC & 2 & 62916 & 31458 & 56.90 & 0.000 \\
\hline AXBXC & 6 & 84063 & 14010 & 25.34 & 0.000 \\
\hline Error & 216 & 119416 & 553 & - & - \\
\hline Total & 239 & 842371 & - & - & - \\
\hline
\end{tabular}

According to the results of this analysis, the effects of the main factors including wood species (A), joint techniques (B), and adhesive type (C) were found to be statistically significant at the level of 0.05 . Furthermore, two factor interactions of wood species $\mathrm{x}$ joint techniques $(\mathrm{A} \times \mathrm{B})$, wood species $\mathrm{x}$ adhesive type $(\mathrm{A} \times \mathrm{C})$, joint techniques $\mathrm{x}$ adhesive type $(\mathrm{B} \times \mathrm{C})$ were also statistically significant $(p \leq 0.05)$. Three factor interactions of wood species $\mathrm{x}$ joint techniques $\mathrm{x}$ adhesive type $(\mathrm{A} \times \mathrm{B} \times \mathrm{C})$ were also statistically significant $(\mathrm{p} \leq 0.05)$. Therefore, the least significant difference multiple comparisons procedure at 5 percent significance level were 
performed to determine the mean differences of compression strength values of tested specimens considering the effect of wood species, joint techniques, and adhesive type interaction.

When the comparison results of wood species were examined, it was seen that the highest moment capacity was obtained in oak woods. There was no statistically significant difference between the other wood species. The density of oak is higher than the density of the other woods used in the experiments. According to the results, it is possible to say that the density in the compression strength increases the moment capacity. Comparison results according to wood species are given in Tab. 7 .

Tab. 7: Results of mean comparisons of bending moment resistances under compression for wood species.

\begin{tabular}{|l|c|c|}
\hline \multirow{2}{*}{ Wood species } & \multicolumn{2}{|c|}{ Bending moment resistances under compression $(\mathrm{N} \cdot \mathrm{m})$} \\
\cline { 2 - 3 } & $\mathrm{X}$ & $\mathrm{HG}$ \\
\hline Scotch pine & 147.17 & $\mathrm{~B}$ \\
\hline Oriental beech & 149.64 & $\mathrm{~B}$ \\
\hline Oak & 173.15 & $\mathrm{~A}$ \\
\hline Chestnut & 145.31 & $\mathrm{~B}$ \\
\hline
\end{tabular}

When the comparison results of the joint techniques were examined, it was seen that the highest moment capacity was obtained in the half lap joints. This was followed by mortise and tenon and dowel joints. The reason why half lap and mortise and tenon joints give better results is because of the fact that it is believed that the joining surface area of these joints is larger. The dowel joints are much lower than the joining surface area. According to the main factor of the joining techniques, the comparison results are given in Tab. 8.

Tab. 8: Results of mean comparisons of bending moment resistances under compression for joint techniques.

\begin{tabular}{|l|c|c|}
\hline \multirow{2}{*}{ Joint techniques } & \multicolumn{2}{|c|}{ Bending moment resistances under compression $(\mathrm{N} \cdot \mathrm{m})$} \\
\cline { 2 - 3 } & $\mathrm{X}$ & $\mathrm{HG}$ \\
\hline Dowel & 100.90 & $\mathrm{C}$ \\
\hline Half lap & 191.12 & $\mathrm{~A}$ \\
\hline Open mortise and tenon & 169.44 & $\mathrm{~B}$ \\
\hline
\end{tabular}

When the comparison results of the adhesive type were examined, it was determined that PVAc gave better results than PU. This can be said to be due to the better penetration of the adhesive into the pores of the woods in the joints made with PVAc. Comparison results according to adhesive type are given in Tab. 9.

Tab. 9: Results of mean comparisons of bending moment resistances under compression for adhesive type.

\begin{tabular}{|l|c|c|}
\hline \multirow{2}{*}{ Adhesive type } & \multicolumn{2}{|c|}{ Bending moment resistances under compression (N.m) } \\
\cline { 2 - 3 } & $\mathrm{X}$ & $\mathrm{HG}$ \\
\hline $\mathrm{PVAc}$ & 171.21 & $\mathrm{~A}$ \\
\hline $\mathrm{PU}$ & 136.43 & $\mathrm{~B}$ \\
\hline
\end{tabular}

When the wood species, joint technique, and adhesive type triple comparison results are examined, the highest moment capacity was obtained with oak wood half lap joint. The lowest moment capacity is obtained in dowel joints in scotch pine wood. It was determined that the PVAc 
was more successful than the PU. Tab. 10 shows the results of wood species, joint technique, and adhesive type three-way interaction with confidence intervals.

Tab. 10: Results of mean comparisons for three-way interaction with confidence intervals.

\begin{tabular}{|c|c|c|c|c|c|c|}
\hline \multirow{2}{*}{ Adhesive } & \multirow{2}{*}{$\begin{array}{c}\text { Joint } \\
\text { technique }\end{array}$} & \multirow{2}{*}{$\begin{array}{c}\text { Wood } \\
\text { species }\end{array}$} & \multirow{2}{*}{ Mean } & \multirow{2}{*}{ Std. Error } & \multicolumn{2}{|c|}{ 95\% Confidence interval } \\
\hline & & & & & Lower bound & Upper bound \\
\hline \multirow{12}{*}{ PU } & \multirow{4}{*}{ dowel joint } & beech & 125.16 & 7.44 & 110.50 & 139.81 \\
\hline & & chestnut & 116.14 & 7.44 & 101.48 & 130.76 \\
\hline & & oak & 99.70 & 7.44 & 85.05 & 114.31 \\
\hline & & scotch pine & 78.48 & 7.44 & 63.83 & 93.14 \\
\hline & \multirow{4}{*}{ half lap joint } & beech & 176.60 & 7.44 & 161.95 & 191.25 \\
\hline & & chestnut & 135.25 & 7.44 & 120.50 & 149.80 \\
\hline & & oak & 123.08 & 7.44 & 108.33 & 137.63 \\
\hline & & scotch pine & 188.77 & 7.44 & 174.12 & 203.42 \\
\hline & \multirow{4}{*}{$\begin{array}{l}\text { mortise and } \\
\text { tenon joint }\end{array}$} & beech & 86.44 & 7.44 & 71.79 & 101.10 \\
\hline & & chestnut & 116.63 & 7.44 & 102.08 & 131.38 \\
\hline & & oak & 203.17 & 7.44 & 188.42 & 217.72 \\
\hline & & scotch pine & 187.78 & 7.44 & 173.03 & 202.33 \\
\hline \multirow{12}{*}{ PVAc } & \multirow{4}{*}{ dowel joint } & beech & 101.82 & 7.44 & 87.16 & 116.48 \\
\hline & & chestnut & 115.08 & 7.44 & 100.47 & 129.77 \\
\hline & & oak & 110.30 & 7.44 & 95.65 & 124.94 \\
\hline & & scotch pine & 60.45 & 7.44 & 45.80 & 75.11 \\
\hline & \multirow{4}{*}{ half lap joint } & beech & 203.18 & 7.44 & 188.43 & 217.73 \\
\hline & & chestnut & 233.87 & 7.44 & 219.22 & 248.52 \\
\hline & & oak & 281.65 & 7.44 & 266.90 & 296.20 \\
\hline & & scotch pine & 186.67 & 7.44 & 172.02 & 201.32 \\
\hline & \multirow{4}{*}{$\begin{array}{l}\text { mortise and } \\
\text { tenon joint }\end{array}$} & beech & 204.78 & 7.44 & 190.03 & 219.33 \\
\hline & & chestnut & 154.87 & 7.44 & 140.22 & 169.52 \\
\hline & & oak & 221.10 & 7.44 & 206.45 & 235.85 \\
\hline & & scotch pine & 180.84 & 7.44 & 166.19 & 195.49 \\
\hline
\end{tabular}

The bending moment resistance results under compression loading obtained from this study have been also compared with the results in some similar studies in literature. Bending moment capacity values of $\mathrm{L}$-shaped corner joints under compression obtained from this study and results of the literature are very close to each other for the dowel and mortise \& tenon joints constructed of beech and pine (Kasal et al. 2015, Kasal et al. 2016, Vassiliou et al. 2016). Furthermore, there are also some studies in literature related to bending moment capacities of T-shaped middle joints for dowel and mortise \& tenon joints constructed of beech and pine (Efe et al. 2005, Erdil et al. 2005, Kasal et al. 2013, Bardak et al. 2017). When the bending moment resistance values obtained from these mentioned studies are compared with the bending moment resistance values of this study, it can be seen that there is consistency between the results of L-shaped corner joints and T-shaped middle joints under compression loading. However, it is also expected that as in tensile test results; there will be some differences between the bending moment resistance values due to the differences in specimen shapes, specimen sizes, and corresponding moment arms.

It is clear that from the all those studies, generally beech yielded better bending moment resistance results than pine, and mortise \& tenon joints gave higher bending moment resistances 
than dowel joints for under both tension and compression loads. When the studies are observed in literature, it can be seen that bending moment resistances under tension and compression are in a linear relationship with the density of wood species.

\section{CONCLUSIONS}

In this study, bending moment resistances of L-shaped corner joints constructed of four wood species, three joint techniques and two different adhesive types were compared under tension and compression loadings. As a result of the statistical analyses of the values obtained from the laboratory tests; in terms of bending moment resistance under compression, oak specimens showed more strength than other wood species, while chestnut specimens gave the highest bending moment resistance under tension. It could be explained by the fact that the density of oak and chestnut are higher than the other species tested in this study. It could be concluded that, higher moment resistance can be obtained by utilizing high density wood species in the construction of L-shaped frame joints.

In case of the joint technique; for both tension and compression tests, the highest bending moment resistances were obtained with the half lap joints, and mortise \& tenon joints. Here, it could be deduced that the size of gluing surface area was effective. In the case of adhesive type; best results were obtained with PVAc. This may be due to the fact that the PVAc adhesive better penetrates the pores of the wood. The viscosity of the PU adhesive is higher. As PU cures, it gains volume. Therefore, it is likely that PU does not penetrate well into the pores of wood and there is no strong interlocking bond between the adhesive and wood substance. Thus, it could be concluded that as an adhesive type, PVAc would provide ease of use, more strength and cost effectiveness.

When three-way interactions were examined; the highest bending moment resistances in both tension and compression loading were obtained with PVAc glued half lap joints constructed of chestnut and oak while the lowest results was obtained with PVAc glued dowel joints constructed of scotch pine.

The results of this study provide experimental information on the bending moment resistances of L-shaped furniture joints under tension and compression loadings, which will in turn help optimize furniture engineering design and construction of furniture joints with these kinds of techniques.

\section{ACKNOWLEDGMENTS}

The authors would like to thank to all technical staff in Department of Furniture \& Decoration, Gazi University and Dekupe R\&D Co. Ltd. for contributing to the success of this study.

\section{REFERENCES}

1. ASTM D-143, 1994: Standard test methods for small clear specimens of timber.

2. ASTM D 4442, 2001: Standard test methods for direct moisture content measurement of wood and wood-base materials. 
3. Aman, R.L, West, H.A, Cormier, D.R., 2008: An evaluation of loose tenon joint strength. Forest Products Journal 58: 61-64.

4. Bardak, T., Tankut, A.N., Tankut, N., Aydemir, D., Sözen, E., 2017: The bending and tension strength of furniture joints bonded with polyvinyl acetate nanocomposites. Maderas-Ciencia y Tecnologia 19(1): 51-62.

5. Bustos, C., Hernandez, H., Beauregard, R.E., Mohammad, M., 2011: Effect of endpressure on the finger-joint quality of black spruce lumber: A microscopic analysis. Maderas-Ciencia y Tecnologia 13(3): 319-328.

6. Cagatay, K., 2011: Comparison of the strength properties of different joint techniques of frame construction furniture. PhD. Thesis, Gazi Unıversity Institute of Science and Technology, Ankara, 244 pp.

7. Chen, G.F., Walworth, G., 2001: Two-part polyurethane adhesive for structural finger joints. U.S. Patent No. 7655312B2.

8. Dalvand, M., Ebrahimi, G., Haftkhani, A.R., Maleki, S., 2013: Analysis of factors effecting diagonal tension and compression capacity of corner joints in furniture frames fabricated with dovetail key. Journal of Forest Research 24: 155-168.

9. Derikvand, M., Ebrahimi, G., 2014: Finite element analysis of stress and strain distributions in mortise and loose tenon furniture joints. Journal of Forestry Research 25(3): 677-681.

10. Dzincic, I., Skakic, D., 2012: Influence of type of fit on strength and deformation of oval tenon-mortise joint. Wood Research 57(3): 469-477.

11. Eckelman, C.A., 2003: Textbook of product engineering and strength design of furniture. Purdue University Press, West Lafayette, Indiana, $174 \mathrm{pp}$.

12. Eckelman, C., Haviarova, E., Erdil, Y. Z., Tankut, A., Akcay, H., Denizli, N., 2004: Bending moment capacity of round mortise and tenon furniture joints. Forest Products Journal 54(12): 192-197.

13. Efe, H., Zhang, J.L., Erdil, Z. Y., Kasal, A., 2005: Moment capacity of traditional and alternative T-type end-to-side grain furniture joints. Forest Products Journal 55(5): 69-73.

14. Erdil, Z. Y., Kasal, A., Eckelman, C.A, 2005. Bending moment capacity of rectangular mortise and tenon furniture joints. Forest Products Journal 55(12): 209-213.

15. Franke, B., Schusser, A., and Müller, A., 2014: Analysis of finger joints from beech wood. In: World Conference on Timber Engineering, Quebec, Canada, Pp 10-15.

16. Hu, W.G., 2015: Study of finite element analysis of node in solid wood structure furniture based on ANSYS. Furniture \& Interior Design 62(4): 575-586.

17. Hu, W.G., Guan, Y.G., 2017: Research on withdrawal strength of mortise and tenon joint by numerical and analytic methods. Wood Research 46(11): 65-67.

18. Hüyük, H., Musica, M., 2014: Analysis of elastic-plastic interference-fit joints. 11 ${ }^{\text {th }}$ International Conference on Technology of Plasticity, ICTP 2014, Pp 19-24.

19. Hrovatin, J., Prekrat, S., Berginc, J., Šernek, M., Zupančič, A., Oblak, L., Medved, S., 2013: Strength comparison of joints at window frames. Drewno Pr Nauk Donies Komunik 56: $127-135$.

20. Imirzi, H.O., Smardzewsk1, J., Dongel, N., 2015: Method for substitute modulus determination of furniture frame construction joints. Turkish Journal of Agriculture and Forestry (39): 775-785.

21. Kamperidou, V., Barboutis, I., Vassiliou, V., 2011: Correlation between bending and tension strength of corner and middle joints constructed with beech and poplar wood. Ann Warsaw University of Life Sciences 73: 44-50. 
22. Kasal, A., Eckelman, C., Haviarova, E., Erdil, Y.Z., Yalcin, I., 2006: Bending moment capacities of $\mathrm{L}$-shaped mortise and tenon joint under compression and tension loading. BioResources 10(4): 7009-7020.

23. Kasal, A., Haviarova, E., Efe, H., Eckelman, C.A, Erdil, Y.Z., 2013. Bending moment capacity of rectangular mortise and tenon furniture joints. Wood and Fiber Science 45(3): 287-293.

24. Kasal, A., Smardzewski, J., Kuskun, T., Erdil, Y.Z., 2016: Numerical analyses of various sizes of mortise and tenon furniture joints. BioResources 11(3): 6836-6853.

25. Li, P., 2010: Mechanical analysis for typical mortising joints of wood product with finite element method. Wood Processing Machinery 25(02): 13-15.

26. Murphey, W.K., Rishel, L.E., 1972: Finger joint feasibility in furniture production. Forest Products Journal 22(2): 30-32.

27. Nicholls, T., Crissan, R., 2002: Study of the stress-strain state in corner joints and box-type furniture using Finite element analysis (FEA). Holz als Roh- und Werkstoff 60: 66-71.

28. Prekrat, S., Smardzewski, J., 2010: Effect of glue line shape on strength of mortise and tenon joint. Drvna Industrija 61: 223-228.

29. Wilczyński, A., Warmbier, K., 2003: Effect of joint dimensions on strength and stiffness of tenon joints. Folia Forestalia Polonica 34: 53-66.

30. Vassiliou, V., Barboutis, I., Kamperidou, V., 2016: Strength of corner and middle joints of upholstered furniture frames constructed with black locust and beech wood. Wood Research 61(3): 495-504.

\author{
Selçuk Demirci \\ Ege University \\ Department of Wood Science and Furniture Design \\ 35000 IZMIR \\ TURKEY \\ Harun Diler \\ Akdeniz University \\ Department of Furniture Design, \\ School of Technical Sciences \\ o7000 ANTAlya \\ TURKEY \\ Ali Kasal \\ Mugla Sitki Kocman University \\ Department of Wood Products Industrial Engineering \\ 48000 Mugla \\ Turkey \\ Yusuf ZiYa ERdiL \\ Mugla Sitki Kocman University \\ Wood Products Industrial Engineering \\ 48000 Mugla \\ TuRKeY \\ *Corresponding author: erdil@mu.edu.tr
}

